\title{
European cities in the process of economic integration: towards structural convergence
}

\author{
Christian Longhi • Antonio Musolesi
}

Published online: 26 January 2007

(C) Springer-Verlag 2007

\section{Erratum to: Ann Reg Sci DOI 10.1007/s00168-006-0104-4}

Due to an unfortunate mistake Eq. (2) was published with an error in the first line. The equation is given correctly below.

The equation should be

$$
y_{i t}^{*}=\beta I_{i t}+x_{i}^{\prime} \delta+v_{i}+\eta_{i t}
$$

The online version of the original article can be found at http://dx.doi.org/10.1007/s00168-006-0104-4.

C. Longhi $(\varangle)$

Gredeg, CNRS and University of Nice Sophia Antipolis, 250 rue A. Einstein,

Sophia-Antipolis, Valbonne 06560, France

e-mail: christian.longhi@idefi.cnrs.fr

\section{A. Musolesi}

CERIS DSE CNR, via Bassini 15, Milan 20133, Italy

A. Musolesi

INRA UMR CESAER, 26 Bd Dr Petitjean, BP 87999, Dijon Cedex 21079, France 